any anterior one. The pulse, during the spared some expense, and most probably disease, ranged from 90 to 100 beats per have gained some information), and having minute. During the morning remissions it done so, asked $\mathbf{M r}_{\mathrm{r}}$. May if he should sumwas compressed and low ; but towards even- mon the attendance of the medical witnesses ing became firmer, fuller, and somewhat re. on the inquest, who at once told him that no doubling to the feel.

The patient was of a nervo-sanguineous constitution, and rather robust in appearance.

Heptonstall, near Halifax, Yorkshire, July 27 th, 1838.

\title{
INQUESTS AT WINDSOR.
}

\section{To the Editor of The Lancer.}

SrR:-When your Coroners' Bill was carried through Parliament, you believed, no doubt, that you had not only provided for the remuneration of medical men, but improved an important judicial tribunal ; I legret, however, to say, that the reverse of this seems to be the case, for since that period, and your advocating the fitness of medical men for the oflice of coroner, it would appear to be the principal aim of legal coroners, in all parts of the country, to couvince the public that the services of medical men are not even necessary to give evidence on an inquest; and that if you, in in your legislative capacity, insist on their being paid when so employed, they, in the exercise of their judicial authority, will take care that they shall not be called upon, since they can no longer compel their attendance gratuitously; nay, moreover, they are resolved that your generous efforts on behalf of the profession shall be thwarted, though Justice herself, and their own duty, be sacrificed in the attempt. I shall now give you a specimen of leyal wisdom and fitness for the office on the part of Mr. May, of Reading, Coroner for the County of Berks.

I was sent for on the morning of Thursday week last to see a boy who had been run over by a waggon, about a mile from hence, and very seriously hurt, the wheel having passed over the abdomen. He died on the Saturday morning following. On the day afterwards (on the Sunday morning) I was summoned to a public-house, close adjoining the other, to see a child five months old, who'was found dead by its mother's side on her awaking, being perfectly well, as she alleged, on going to bed; the maid servant slept with the mother and child, the poor woman's husband having been recently sent to the Fleet. On examining the child it became at once apparent to me what had been the cause of death. On that same day the constable of Old Windsor went over to Reading, a distance of twenty miles, to report the cases to the Coroner (the district of the Coroner for this borough did not extend, unfortunately, to within a few yards of these louses, or the county would have been medical evidence was necessary! Now, Sir, what do you think of this? We have heard a good deal of the "Oracle at Delphos" as well as "Sir Oracle," but I opine that these oracles must bave been fools compared with the modern one of Reading. Well, down came the Coroner of the county, and quickly disposed of the first case by returning a verdict of "accidental death," though you will allow that from the time which elapsed between the accident and the dissolution it did not follow as a matter of course that the one was a necessary and certain consequence of the other ; no matter, that was all apparently settled beforehand. The body of the infant next came sul judice. The mother and servant girl were examined, and what do you imagine was the result of his profound inquiries? A verdict of "Found dead."

Why, Sir, every old woman in the parish knew this before Mr. May came a journey of twenty miles, and at a great expense to the county, to inform them. Now, it must appear somewhat extraordinary to you and the profession that the cause of death should not have been investigated instead of simply recording the fact, for you are well aware that death might have ensued from a variety of causes in this case, such, for instance, as convulsions from dentition, \&c., from over. laying, from the administration of improper medicine, and from many other causes that none but a medical man could detect; yet here is an important judicial proceeding set at rest at the onset, through the ignorance or the perverseness of the legal presiding officer neglecting to obtain the only kind of evidence that could have elucidated the facts. I think, Sir, you will agree with me in admitting that the sooner the costly services of such a Coroner are dispensed with the better. I remain, Sir, your obedient servant,

Windsor, Aug. 6th, 1838.

William Moss.

\section{ACUPUNCTURE OF GANGLIONS.}

\section{To the Editor of THE LANCET.}

SIr:-Among the various diseases for which acupuncture has been recommended, I am not aware of its having heretofore been tried in the unimportant but sometimes intractable case of ganglion. The following may perhaps appear deserving of a place in your columns.

A young lady under my care having been affected with a ganglion of considerable size on the extensor tendons of the foot, which 